\title{
Masonry infilled frames - contemporary structural concepts
}

\author{
I. Radić, T. Dokšanović, D. Markulak \& B. Pervan \\ Faculty of Civil Engineering and Architecture, Josip Juraj Strossmayer University of Osijek, Osijek, \\ Croatia
}

\begin{abstract}
Infilled frames were the focus of numerous experimental tests which have been executed to investigate the seismic behaviour of these systems, but the task remains challenging due to significantly pronounced nonlinear structural behaviour. The infill inevitably changes the "common" and well-known structural behaviour of bare steel and RC frames into a more complex interactive behaviour, strongly influenced by randomness introduced by heterogeneity of infill. While positive effects such as improved strength can be treated as redundant and consequently neglected in design to vertical forces, negative effects cannot be ignored in seismic areas. In the last decade, a few comprehensive research studies on RC and steel masonry infilled frames were carried out at the Faculty of Civil Engineering and Architecture Osijek. In this paper, the main conclusions from these studies are provided together with a review of contemporary structural solutions for steel and RC masonry infilled frames.
\end{abstract}

\section{INTRODUCTION}

Masonry products made of clay or lightweight concrete are commonly used as infill panels for reinforced concrete $(\mathrm{RC})$ and steel frames, primarily due to their favourable characteristics availability, acceptable cost, good physical properties, easy production and erection. The presence of such infill strongly affects the behaviour of the frame, but there are still no specific methods nor detailed design rules for the analysis of these structures. The structural behaviour of masonry-infilled frames is strongly nonlinear due to the influence of parameters such as material characteristics of its constituent parts, applied construction procedure, structural configuration, geometric properties, load characteristics etc. (Markulak et al., 2013). The main difficulty from a structural point of view is that the effects of masonry infill can be beneficial (increased stiffness and loading capacity) and detrimental (prying actions in connections caused by diagonal compression forces, limited displacement capacity, short column effect), depending on listed parameters.

The specific interest of past and ongoing research studies is the structural behaviour of masonry-infilled frames subjected to earthquake loading. Namely, while positive effects can be treated as redundant and consequently neglected, negative effects cannot be ignored in active seismic areas. The main reasons are higher seismic demand due to increased stiffness and possibly limited ductility due to earlier onset of plastic deformations. This type of structural behaviour of masonry-infilled RC and steel frames was investigated experimentally and numerically at the Faculty of Civil Engineering and Architecture Osijek (FCEA), within several research studies (Grubišić and Sigmund, 2014b, Grubišić and Sigmund, 2014a, Markulak et al., 2020, Markulak et al., 2013, Sigmund et al., 2014, Zovkic et al., 2013). These studies can be furthered by additional experimental and numerical studies, as well as evaluated from additional points of view. Therefore, the main objective of this paper is to offer a selection of comparisons between experimental data which will give insight into the behaviour of such 
systems. By outlaying obtained conclusions along with a discussion of typical contemporary structural solutions and design methods for steel and RC masonry infilled frames, it is possible to identify future research studies.

\section{CONTEMPORARY STRUCTURAL SOLUTIONS - STEEL VS. RC MASONRY INFILLED FRAMES}

Given the differences in structural properties of steel and RC frames, whether considered as standalone or in combination with masonry infill, there are generally different approaches to their design in regards to earthquake loading. The boundaries between these approaches have recently been less clear, but two distinct approaches can be identified. Namely, the typical design approach to RC frames is to incorporate the contribution of masonry infill into the overall response of the structure, which often results in proposals of various methods of additional infill strengthening. On the other hand, although there are examples of investigation of retrofitting and strengthening of steel infilled frames, inventing and establishing various forms of isolation of the masonry panel from the surrounding frame may be considered as a typical approach applied for steel frames. The differences in stiffness, strength and ductility of RC and steel frames combined with appropriate characteristics of masonry infill are key reasons for such opposite approaches.

The typical methods for infill strengthening in case of RC frames are the use of wire mesh reinforcement with cover mortar (Grubišić and Sigmund, 2014a), the connection of unreinforced infill wall to the surrounding frame by steel dowels (Grubišić and Sigmund, 2014a), use of more advanced materials for the cover of the infill wall like a designed highperformance fibre reinforced cementitious composite called ECC (Dehghani et al., 2015), glass fibre reinforced polymer (GFRP) (Abdel-Hafez et al., 2015), carbon fibre reinforced polymers (CFRP) (Altin et al., 2008), textile-reinforced mortar (TRM) with strengthening meshes based on BCRs (composite rod composed of external polyester protection of a reinforcing core composed of distinct types of fibres) (Martins et al., 2015), etc. In case of steel frames, there are typical approaches with forms of isolation of the masonry panel from the frame (mitigation of infill-frame interaction) or with the implementation of structural measures to modify the "natural" behaviour of an infill panel. Some of proposed solutions are partition of the infill panel into two or more zones in order to allow sliding (Preti et al., 2016), introducing so-called friction sliding fuses (Mohammadi and Akrami, 2010) or other types of seismic isolators (Tsantilis and Triantafillou, 2018) between the infill and frame, combining of various compression grades od masonry infill to achieve controlled cracking and separation (Markulak et al., 2020, Markulak et al., 2013), the invention of various interlock mechanisms for infill blocks instead of using mortar (Palios et al., 2017), etc.

Although the scientific community made a considerable effort to fully understand and improve the structural behaviour of masonry infilled frames, there is still no uniform and generally accepted methodology. This conclusion is substantiated by various solutions which are seemingly opposite to each other - e.g. in (Markulak et al., 2013) the main intention is to use masonry infill within steel frames up to a certain level of load and ensure the separation of infill for higher loads, whereas in (Tsantilis and Triantafillou, 2018) application of thin layers of cellular materials at the frame-infill contact area delays infill exploitation to higher load levels. There are examples of seemingly opposite solutions in infilled RC frames also.

\section{EXPERIMENTAL RESEARCH STUDIES AT FCEA OSIJEK}

This chapter presents the results of selected experimental work on frames with masonry infill loaded cyclicly, conducted at FCEA Osijek. These experimental investigations can be divided into three groups according to the frame material and objectives: testing of the steel frames with masonry infill (Markulak et al., 2020, Markulak et al., 2013, Radić, 2012), testing of reinforced concrete frames with masonry infill (Sigmund et al., 2014, Zovkić, 2013, Zovkic 
et al., 2013) which, after testing, were repaired and strengthened using various techniques and retested ((Grubišić, 2016, Grubišić and Sigmund, 2014b, Grubišić and Sigmund, 2014a). To be able to assess the impact of infill on the behaviour of the system, in addition to testing the frame with masonry infill, the behaviour of bare steel and $\mathrm{RC}$ frames was also experimentally determined.

\subsection{Test setup and procedure}

Analyzed frame configurations were tested in the steel reaction frame, shown in Figure 1, in a series of quasi-static gradually increasing load cycles until the failure of masonry infill or the frame. Hydraulic actuators, with the capacity of $335 \mathrm{kN}$ and a stroke of $150 \mathrm{~mm}$, were situated to the left and right of the specimen with $500 \mathrm{kN}$ capacity load cells monitoring the force. The displacement of frame beams, infill panels at bottom and top, and along the diagonals was monitored with LVDTs (range of $\pm 50 \mathrm{~mm}$ ). In case of significant damage of the masonry infill, the cyclic load pattern was interrupted and loading continued in a pushover manner (i.e. on one side).

\subsection{Steel frames with masonry infill}

The investigation of the behaviour of masonry infilled steel frames was executed in two phases. In the first phase commercially available masonry units were used for infill construction, while in the second phase the masonry infill consisted of specially developed masonry units made of recycled brick aggregate and ground expanded polystyrene (Markulak et al., 2018)

In the first phase of the research, rigid steel frames with three different types of masonry infill were built: "strong" infill made of hollow clay masonry units (SF-R-C), "weak" infill built of light autoclaved aerated concrete (AAC) units (SF-R-AAC) and combined infill made with a "weaker" AAC units (with drilled vertical holes) located beside the columns, while the "stronger" clay units occupied the rest of the infill (SF-R-CA). The combined masonry infill enabled a partial separation from the frame at by crushing the weaker AAC masonry units, thus minimizing negative effects of the infill at higher loads. The main goal was to take advantage of the beneficial effects of infill (increased stiffness and strength) up to a certain load level and to preserve ductile behaviour of the bare steel frame at higher load levels.

Compressive strength of hollow clay wall units and cement-lime mortar were 11.8 MPa and 5.0 MPa, respectively, while the compressive strengths of AAC elements and thin-layered adhesive mortar (glue) were 2.0 $\mathrm{MPa}$ and 9.1 MPa, respectively. Steel frames consisted of HEA 120 members with a nominal steel grade of S275.

The test results, shown in Table 1 and Figure 2, demonstrated that the highest load-bearing capacity was achieved on frames with AAC infill. The high strength of the mortar/glue
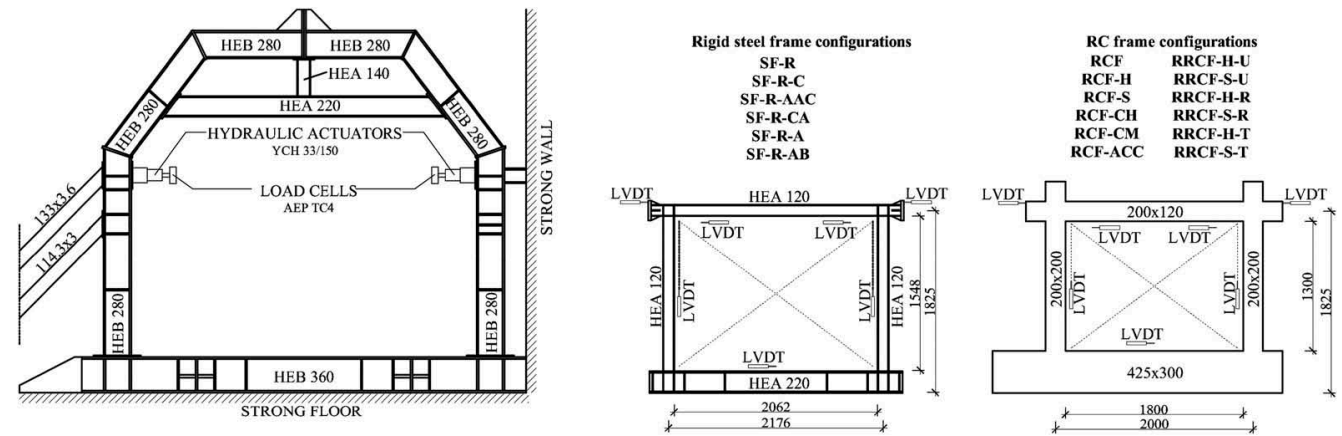

Figure 1. Steel reaction frame and tested steel/RC frame configurations. 


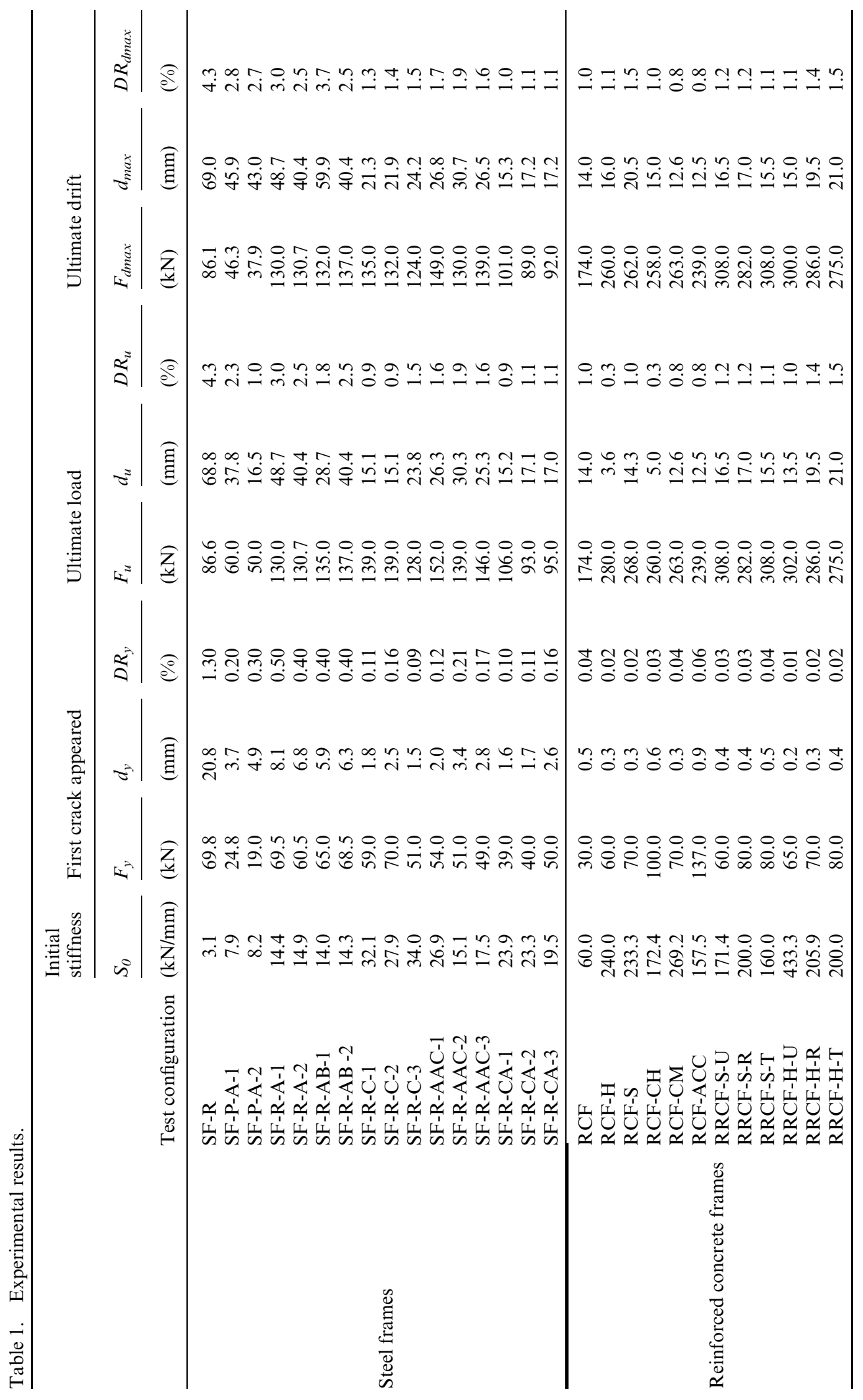


a)

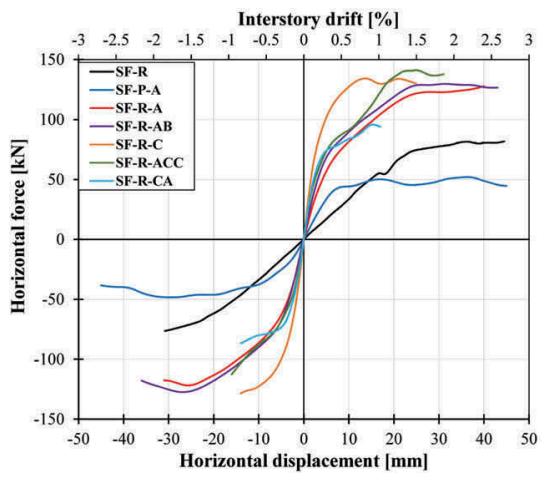

b)

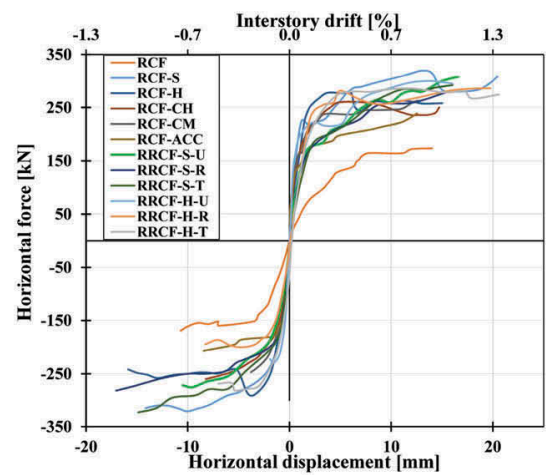

Figure 2. Hysteresis envelope curves of tested specimens. a) Infilled steel frames, b) Infilled RC frames.

enabled a more compact behaviour of the infill panel with a large number of minor cracks without extensive crushing and separation from the frame. Steel frames with clay units had the highest initial stiffness, followed by frames with combined masonry infill and frames with AAC infill. Experimental results proved the possibility of using a relatively simple solution to control the damage of masonry infill in laterally loaded steel frames - by partially separating the infill from the steel frame at certain levels of drift, it was possible to eliminate the main detrimental effects of the infill.

As a continuation of the previously described research, a special type of masonry units was developed at FCEA Osijek. The main idea was to create a masonry infill that has minimal detrimental effects on the steel frame while retaining positive characteristics of the masonry infill such as increased initial stiffness of the system. This achievement of this goal was attempted by developed masonry units with lower stiffness and strength, made of selfcompacting concrete with embedded crushed brick and ground polystyrene which makes them environmentally favourable compared to standard masonry units. In addition to a standard block shape (Type A), a special weakened unit was developed with one vertical wall removed along the sidewall (Type B). The tests included investigation of the behaviour of a rigid steel frame infilled with masonry units of Type A (SF-R-A), a rigid steel frame infilled with a combination of masonry units type $A$ and type $B$ which masonry units were located alongside the column-masonry contact patch (SF-R-AB), and a pinned steel frame infilled with type A masonry units (SF-P-A). In addition to testing the behaviour of frames with masonry infill, a rigid steel frame was tested (SF-R).

Normalized compressive strength of new masonry units was determined as 2.97 MPa, and mean compressive strength of mortar was $5.96 \mathrm{MPa}$. Pinned steel frames consisted of HEA 280 members and rigid frames of HEA 120 members, with the nominal steel grade being S235.

Experimental results show that infilled rigid steel frames (SF-R-A and SF-R-AB) have higher initial stiffness and ultimate load capacity compared to rigid steel frame without infill (SF-R) and pinned infill frames (SF-P-A). A comparison of the results between rigid steel frames with infill shows that the planned separation of the frame and the masonry infill was not achieved. The SF-R-A and SF-R-AB configurations show very similar fracture mechanisms dominated by a clear diagonal formation of concentrated strain, with minimal detrimental effects to the steel frame.

\subsection{Reinforced concrete frames with masonry infill}

The investigation of the influence of masonry infill on the behaviour of reinforced concrete (RC) frames included the construction and testing of a bare RC frame (RCF) and frames with three different types of masonry units: high strength perforated clay brick blocks (RCF-CH), medium strength perforated clay brick blocks (RCF-CM) and low strength lightweight aerated autoclaved 
concrete blocks (RCF-ACC). The dimensions of the RC frame, built of concrete $\mathrm{C} 30 / 37$ and reinforcement grade B500B, were $2.2 \mathrm{~m} \times 1.5 \mathrm{~m}$ with columns and beam cross-section $20 \times 20 \mathrm{~cm}$ and $12 \times 20 \mathrm{~cm}$. The experimentally determined mean compressive strengths of masonry units for the RCF-CH, RCF-CM, and RCF-ACC configurations were $13.21 \mathrm{MPa}, 3.87 \mathrm{MPa}$, and 13.89 $\mathrm{MPa}$, respectively. RCF-CH and RCF-CM configurations were built with cement-lime mortar whose compressive strengths were 5.11 MPa and 5.01 MPa, while for the RC-ACC configuration an adhesive mortar (glue) with a compressive strength of $13.89 \mathrm{MPa}$ was used.

Experimental results show an evident and expected contribution of the masonry infill to initial stiffness and an increase of ultimate load capacity of frames depending on the infill strength. The fracture mechanisms in RC frames with clay masonry units were similar - cracks spread horizontally along the masonry bed joints and create a sliding mechanism. A combined fracture mechanism was observed for the frame infilled with AAC masonry units - diagonal cracks at lower load levels followed by a small number of horizontal cracks formed at higher load levels.

$\mathrm{RC}$ frames damaged in previously described tests were repaired by replacing the spalled concrete with fast setting concrete mortar and infilled with two types of masonry units hollow and solid clay masonry units with a compressive strength of $4.01 \mathrm{MPa}$ and $8.30 \mathrm{MPa}$, respectively. The masonry infill was made by using cement-lime mortar with a nominal strength of $5 \mathrm{MPa}$. The masonry infill was added within the frame by three different techniques: unreinforced infill made of hollow and solid clay masonry units connected to RC frame by dowels (RRCF-H-U and RRCF-S-U), reinforced infill made of hollow and solid clay masonry units connected to RC frame by dowels (RRCF-H-R and RRCF-S-R) and unreinforced infill of hollow and solid clay masonry units strengthened with an additional vertical confining element (tie-column) and connected to RC frame by dowels (RRCF-H-T and RRCF-S-T). Two additional samples of an undamaged reinforced concrete frame with an infill of hollow (RCF-H) and solid clay (RCF-S) masonry units were built, to get an insight into the efficiency of each strengthening technique.

The test results showed that the addition of masonry infill directly affected the strength, stiffness and displacements of the structure under cyclic excitation and that the increase in the ultimate load capacity depended on the type of strengthening. All specimens had relatively small cracks in RC columns and beams as well as vertical and horizontal cracks in the joint mortar between clay solid/hollow units. In solid clay masonry infill cracks performed substantially later than then the hollow clay masonry infill, due to lower lateral stiffness. In almost all models, the first cracks appear due to slip of mortar, especially with solid clay infill.

\section{COMPARISON OF OBTAINED RESULTS AND DISCUSSION}

A summary of gathered experimental data from a wide range of test series on both steel and $\mathrm{RC}$ frames with various infill materials is given in Table 1 . The hysteresis envelope curves are shown in Figure 2, where test configuration designations correspond to previously used in headings 3.2 and 3.3 .

It is clear that structural differences between bare steel and $\mathrm{RC}$ frames also partially reflect on the behaviour of the corresponding infilled systems. Namely, initial stiffness of steel frame systems is generally lower, but drift capacity (ductility) is higher. The increase in initial stiffness and a decrease in ductility with the addition of infill can be applied for both RC and steel systems. A general rule of thumb is that use of infill has the effect of increased initial stiffness with lower ductility. AAC units stand out as being able to ensure a high level of ultimate load capacity, with lower initial stiffness and moderate levels of ductility, and this type of behaviour is additionally amplified when newly designed units in steel frames are used. The lateral system capacity is highly dependent on the frame strength (i.e. material), but relative comparisons between same frame types with different masonry units are possible. Consistency in behaviour can be achieved using solid units as they are compact and there is no side-wall delamination (the weakest link affects the behaviour of the panel). Figure 2 demonstrates that steel frames exhibit three-linear like behaviour whereas a bi-linear relation is more suitable for $\mathrm{RC}$ infilled frames. 
Based on presented research data and results, it can be concluded that the structural behaviour of infilled RC and steel frames do have some common ground. Namely, it seems that it is possible to predict to some extent the influence of the particular infill type on the behaviour of infilled steel and RC frames. Based on these findings certain patterns in behaviour observed in infilled steel frames can be extrapolated to be valid for RC infilled frames, and vice versa. Further work can be done in terms of reliability assessment and design models based on available results.

\section{REFERENCES}

Abdel-Hafez, L. M., Abouelezz, A. \& Elzefeary, F. F. (2015) Behavior of masonry strengthened infilled reinforced concrete frames under in-plane load. HBRC Journal, 11, 213-223.

Altin, S., Anil, Ö., Kara, M. E. \& Kaya, M. (2008) An experimental study on strengthening of masonry infilled RC frames using diagonal CFRP strips. Composites Part B: Engineering, 39, 680-693.

Dehghani, A., Nateghi-Alahi, F. \& Fischer, G. (2015) Engineered cementitious composites for strengthening masonry infilled reinforced concrete frames. Engineering Structures, 105, 197-208.

Grubišić, M. (2016) Modeli ocjene ojačanja armiranobetonskih okvira dodavanjem ispuna pri potresnom djelovanju. Josip Juraj Strossmayer University of Osijek. Faculty of Civil Engineering.

Grubišić, M. \& Sigmund, V. (2014a) Comparison of different strengthening techniques of damaged and weak reinforced-concrete frames. Second European Conference on Earthquake Engineering and Seismology, İstanbul

Grubišić, M. \& Sigmund, V. (2014b) Experimental studies of single bay RC frames with strengthened masonry infill. YOUNG SCIENTIST, 94-107.

Markulak, D., Dokšanović, T., Radić, I. \& Miličević, I. (2018) Structurally and environmentally favorable masonry units for infilled frames. Engineering Structures, 175, 753-764.

Markulak, D., Dokšanović, T., Radić, I. \& Zovkić, J. (2020) Behaviour of steel frames infilled with environmentally and structurally favourable masonry units. Engineering Structures, 204, 109909.

Markulak, D., Radić, I. \& Sigmund, V. (2013) Cyclic testing of single bay steel frames with various types of masonry infill. Engineering Structures, 51, 267-277.

Martins, A., Vasconcelos, G., Fangueiro, R. \& Cunha, F. (2015) Experimental assessment of an innovative strengthening material for brick masonry infills. Composites Part B: Engineering, 80, 328-342.

Mohammadi, M. \& Akrami, V. (2010) An engineered infilled frame: Behavior and calibration. Journal of Constructional Steel Research, 66, 842-849.

Palios, X., Fardis, M. N., Strepelias, E. \& Bousias, S. N. (2017) Unbonded brickwork for the protection of infills from seismic damage. Engineering Structures, 131, 614-624.

Preti, M., Bolis, V. \& Stavridis, A. (2016) Design of masonry infill walls with sliding joints for earthquake structural damage control. Proceedings of the 16th International Brick and Block Masonry Conference (IBMAC'16).

Radić, I. (2012) Ponašanje čeličnih okvirnih građevina sa zidanim ispunom pri djelovanju potresa. Faculty of Civil Engineering. Osijek, J. J. Strossmayer University of Osijek.

Sigmund, V., Zovkić, J. \& Guljaš, I. (2014) Behaviour of RC frame with strong masonry infill in response to cyclic horizontal loading. Tehnicki vjesnik/Technical Gazette, 21.

Tsantilis, A. V. \& Triantafillou, T. C. (2018) Innovative seismic isolation of masonry infills in steel frames using cellular materials at the frame-infill interface. Journal of Earthquake Engineering, 1-18.

Zovkic, J., Sigmund, V. \& Guljas, I. (2013) Cyclic testing of a single bay reinforced concrete frames with various types of masonry infill. Earthquake engineering \& structural dynamics, 42, 1131-1149.

Zovkić, J. (2013) Ponašanje armirano-betonskih okvira s ispunom pri djelovanju potresa. Josip Juraj Strossmayer University of Osijek. Faculty of Civil Engineering. 